\title{
ROOTING OF Araucaria angustifolia: TYPES OF CUTTINGS AND STOCK PLANTS SEX ${ }^{1}$
}

\author{
Ivar Wendling ${ }^{2 *}$, Carlos André Stuepp ${ }^{3}$ and Katia Christina Zuffellato-Ribas ${ }^{4}$
}

\footnotetext{
${ }^{1}$ Received on 06.09.2014 accepted for publication on 11.11.2016.

${ }^{2}$ Embrapa Florestas, Colombo, PR, Brasil. E-mail:<ivar.wendling@embrapa.br $>$.

${ }^{3}$ Universidade Federal do Paraná, Programa de Pós-Graduação em Agronomia - Produção Vegetal, Curitiba, PR, Brasil. E-mail: <carlos.stuepp@ufpr.br>.

${ }^{4}$ Universidade Federal do Paraná, Curitiba, PR, Brasil. E-mail: <kazu@ufpr.br $>$.

*Corresponding author.
}

\begin{abstract}
Araucaria angustifolia is native to Brazil and has always raised economic interest for the qualities of its timber and as a supplier of pine nuts for human consumption. The scarce germination viability of the stored seeds and the possibility to produce rooted cuttings all year round make cuttings propagation a good alternative for the production of plants, giving also the possibility to obtain genetically superior clones. On this basis, we assessed the influence of stock plants sex and type of cuttings (apical and intermediate) on the percentage of survival, rooting and vigor of the cuttings, together with the efficiency of this technique in the production of rooted cuttings of this species. So, cuttings from orthotropic shoots, collected in a clonal garden composed by feminine and masculine plants, had their survival percentages assessed at 60, 90, 120 and 150 days after installation of the experiment (DAI). Rooting in full sunlight area after 180 days, together with vigor characteristics of roots and aerial portion at 120 and 180 DAI were also evaluated. At 180 DAI, apical female cuttings presented the greatest rooting percentage (53.7\%), number of roots (1.2) and average length of roots at the bottom of the rooting tray $(4.4 \mathrm{~cm})$. On the other hand, the applied cuttings procedures showed to be adequate to increase the rooting percentages of the species, which, supported by the fact that this technique is important for the formation of rooted cuttings to be used in the mini-cuttings technique, indicates that it can be considered efficient.
\end{abstract}

Keywords: Brazilian pine; Cloning; Cuttings production.

\section{ENRAIZAMENTO DE Araucaria angustifolia: TIPOS DE ESTACAS E SEXO DAS PLANTAS MATRIZES}

\begin{abstract}
RESUMO - Araucaria angustifolia (araucária) é nativa do Brasil e sempre despertou interesse econômico por suas qualidades madeireiras e como fornecedora de pinhões para alimentação humana. A baixa viabilidade na germinação de suas sementes quando armazenadas e a possibilidade de produzir mudas durante o ano inteiro fazem com que a estaquia se apresente como alternativa para produção de mudas, gerando ainda a possibilidade de obtenção de clones geneticamente superiores. Com base nisso, avaliou-se a influência do sexo das matrizes e o tipo de estaca (apical e intermediária) na sobrevivência, enraizamento e vigor de suas estacas, bem como a eficiencia desta técnica na produção de mudas da espécie. Para tanto, estacas de brotos ortotrópicos coletadas em jardim clonal de plantas masculinas e femininas foram avaliadas quanto à sobrevivência aos 60, 90, 120 e 150 dias após a estaquia (DAI) e o enraizamento a pleno sol aos 180 dias, bem como características de vigor radicial e aéreo aos 120 e 180 DAI. Aos 180 DAI, estacas femininas apicais apresentaram maior enraizamento $(53,7 \%)$, número de raizes $(1,2)$ e comprimento médio de raizes no fundo do tubete $(4,4 \mathrm{~cm})$. Por outro lado, os procedimentos de estaquia utilizados mostraram-se adequados para incrementar os percentuais de enraizamento da espécie, o que, aliado ao fato da técnica ser importante na formação de mudas para a técnica de miniestaquia, indica que a mesma pode ser considerada eficiente.

Palavras-chave: Araucaria; Clonagem; Produção de mudas.
\end{abstract}




\section{INTRODUCTION}

Araucaria angustifolia (Bertol.) Kuntze (Araucariaceae), commonly known as araucaria or Brazilian pine, is naturally present in the south of Brazil, mainly in the oriental and central part of the Brazilian highlands (CARVALHO, 2003). Its wood presents very attractive characteristics, being its use widely recommended for civil construction, paper and cellulose production (MATTOS et al., 2006). These characteristics and the high value added to its wood (DELUCIS et al., 2013) were responsible for the high exploitation of the species in the end of the XIX century. At the same time, the lack of natural resources management in those years, added to the long and delicate reproduction cycle of the species, contributed to the survival of less than $2 \%$ of the original forest formations $(\mathrm{KOCH}$; CORRÊA, 2002).

As most of the conifers, araucaria is sexually propagated. However, the low longevity of its seeds (MOREIRA-SOUZA; CARDOSO, 2003), together with the disadvantages associated to this propagation method, like the impossibility to define sex and the great genetic variability of the seedlings (HARTMANN et al., 2011; DIAS et al., 2012), are contributing to the necessity to improve vegetative propagation techniques (PIRES et al., 2013; WENDLING et al., 2016). Among them, cuttings and mini-cuttings techniques have presented satisfactory and relatively rapid results in the production of genetically superior clones, aiming to the production of wood from a series of forest genera, like Eucalyptus and Pinus sp. (SAYA et al., 2008; HUNT et al., 2011; MAJADA et al., 2011). The same techniques are also applied to species like Dalbergia melanoxylon, Liquidambar styraciflua, Ilex paraguariensis, Khaya senegalensis, Corymbia torelliana x C. citriodora (WENDLING et al., 2007, 2010; BITENCOURT et al., 2009; AMRI et al., 2010; KY-DEMBELE et al., 2011; MCMAHON et al., 2014) among others.

However, the use of those techniques becomes efficient when the ideal characteristics of the material to be propagated are defined (STUEPP et al., 2014), resulting in high rooting and best final use indexes of the propagated plants. Results presented until now for araucaria do not satisfy the expectations of success from the application of this technique for commercial purposes, since rooting is below $25 \%$ (IRITANI; SOARES, 1983), and 30\% (WENDLING; BRONDANI, 2014). The few attempts to establish propagation protocols for the species have presented a series of limitations, mainly concerning efficient methods for rescue and rejuvenation of the adult material (WENDLING et al., 2009), and the plagiotropic growth habit of the lateral shoots (ZANETTE et al., 2011), indicating a recalcitrant behavior of araucaria to vegetative propagation, even with young and very young individuals (originated from seeds) (IRITANI, 1997; PIRES et al., 2013).

Thus, we assess the influence of stock plants sex and type of propagules (apical and intermediate cuttings), on survival, rooting and vigor of roots and aerial parts of cuttings obtained from orthotropic shoots of Araucaria angustifolia, as well as, the efficiency of this technique in the rooted cuttings production of the species.

\section{MATERIALAND METHODS}

The experiment was conducted from August/2007 to February/2008 in the Laboratory of Forest Species Propagation, belonging to Embrapa Florestas, ColomboPR, Brazil (25'20' S and 49 $14^{\prime}$ W, $950 \mathrm{~m}$ ). According to the Köppen classification, the climate in the region is temperate, type $\mathrm{Cfb}$, with temperature of the coldest month between -3 and $18{ }^{\circ} \mathrm{C}$, always humid with evenly distributed rainfall throughout the year and temperature of the hottest month lower than $22^{\circ} \mathrm{C}$.

The stumps of stock plants used in this study came from rooted cuttings produced from shoots of 26 years old trees, established in a provenances and progeny trial, in Colombo-PR. The stock plants, installed in a field clonal garden $(0.5 \mathrm{~m} \times 0.5 \mathrm{~m}$ spacing $)$ were chopped off to obtain basal orthotropic shoots, as detailed in Wendling and Brondani (2014).

From orthotropic shoots of each sex (male and female plants), two types of cuttings were prepared, the first from the apical region of the branches (apical cuttings) and the second from the intermediate section of the same branches, with a straight cut above the last bud (intermediate cuttings). Booth types of cuttings were prepared with length of $15-20 \mathrm{~cm}$ and diameter of $5-10 \mathrm{~mm}$, with a bevel cut on the base and removal of the aciculae for $1 / 3$ of the length from the basal region, in order to facilitate planting.

Cuttings were decontaminated with sodium hypochlorite solution ( $1 \%$ active chlorine) for 5 minutes (bactericide action), then cleaned with running water and treated with Benomyl ${ }^{\circledR}\left(1 \mathrm{gL}^{-1}\right)$ for 5 minutes (fungicide 
action). Later, treatment of the bases took place with indole-3-butyric acid (IBA), at the concentration of $3000 \mathrm{mg} \mathrm{L}^{-1}$ in hydro-alcoholic solution $(1: 1, \mathrm{v} / \mathrm{v})$ for ten seconds. Cuttings were planted approximately at three centimeters deep in polypropylene trays with capacity of $280 \mathrm{~cm}^{3}$, filled with potting mix composed of a mixture of medium vermiculite and carbonized rice hull $(1: 1, \mathrm{v} / \mathrm{v})$. Trays were placed in a greenhouse with mist irrigation (temperature of $25^{\circ} \mathrm{C} \pm 5^{\circ} \mathrm{C}$ and relative humidity above $80 \%$ ) during 120 days. After permanence in the greenhouse, cuttings went through further acclimatization process in a shade house ( $50 \%$ of shade) during 30 days and then in a full sunlight area for 30 more days to achieve acclimatization with the external environment.

Throughout the experiment, the following variables were assessed: survival percentage of cuttings in greenhouse after 60 and 90 days; survival at the exit of the greenhouse after 120 days (SEGH); survival at the exit of the shade house after 150 days (SESH); rooting in full sunlight after 180 days (RFS). Furthermore, the number and the total length of roots appearing under the trays (cuttings with roots emerging from the hole in the base of the trays) were assessed after 120 days, together with the number of new shoots emitted by the cuttings after 180 days.

The experiment was conducted with a completely randomized design with $2 \times 2$ factorial structure, composed by male and female stock plants and two types of cuttings (apical and intermediate), and from two to four replications per treatment (depending on the availability of samples) and 14 cuttings per experimental unit. The statistical analysis was performed with the Bartlett's test $(p<0.05)$ to assess homogeneity of the variances. Post-hoc Tukey's Honestly Significant Difference (HSD) tests were performed only when significant differences $(\mathrm{P}<0.05)$ were detected by ANOVA. A Pearson's correlation analysis $(\mathrm{p}<0.01)$ was also performed for the SEGH, SESH and RFS variables.

\section{RESULTS}

All treatments presented similar results at 60 days after installation (DAI), with survival percentage above $75 \%$. At 90 days (in the greenhouse) and 120 days at the exit of the greenhouse (SEGH), male intermediate cuttings showed significant reduction in survival rates compared to all others, with values around $50 \%$. Finally, at 150 days, when taken out from acclimatization in shade house (SESH), female apical cuttings showed greatest survival percentage, followed by apical male, intermediate female and lastly by intermediate male (Figure 1).

At $120 \mathrm{DAI}$, the average number of roots in the tray bottom (NRTB) was similar for all treatments, except for the intermediate male cuttings, which did not present visible roots. The average roots length at the trays bottom (RLTB) was similar for apical male $(5.7 \mathrm{~cm})$ and apical female cuttings $(5.0 \mathrm{~cm})$, greater than the results for intermediate female $(3.5 \mathrm{~cm})$ and intermediate male cuttings (no roots) (Figure 2).

At 180 DAI rooting values decreased significantly for cuttings exposed to full sunlight (RFS). Intermediate male cuttings showed low RFS (4.5\%) whereas other types of cuttings did not show significant differences between each other. Male apical cuttings showed greater number of shoots per cutting (NSC), although without a significant difference with apical and intermediate female cuttings (Figure 3 ).

It was also verified high correlation between SEGH and SESH and between SESH and RFS (Table 1).

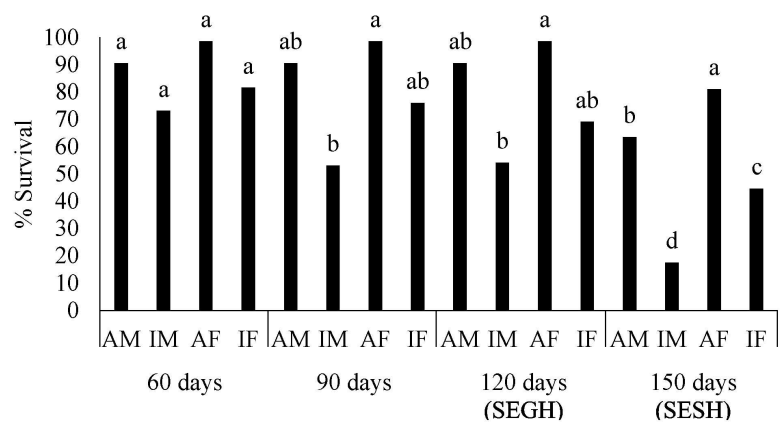

Figure 1 - Percentage of survival of Araucaria angustifolia cuttings in greenhouse (60 and 90 days), at the exit of greenhouse (SEGH) and at the exit of shade house (SESH). Where AM=apical male; $\mathrm{IM}=$ intermediate male; $\mathrm{AF}=$ apical female; $\mathrm{IF}=$ intermediate female. Means $( \pm \mathrm{SE})$ with different letters are significantly different (ANOVA and Tukey's HSD test, $\mathrm{P}<0.05$ )

Figura 1-Porcentagem de sobrevivência de estacas de Araucaria angustifolia em casa de vegetação (60 e 90 dias), na saída da casa de vegetação (SEGH) e saída da casa de sombra (SESH). Onde: $A M=$ macho apical; $I M=$ macho intermediária; $A F=$ fêmea apical; IM=fêmea intermediária. Médias seguidas por mesma letra dentro de cada fase não diferem entre si pelo teste de Tukey a 5\% de probabilidade.

Revista Árvore, Viçosa-MG, v.40, n.6, p.1013-1021, 2016

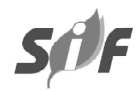



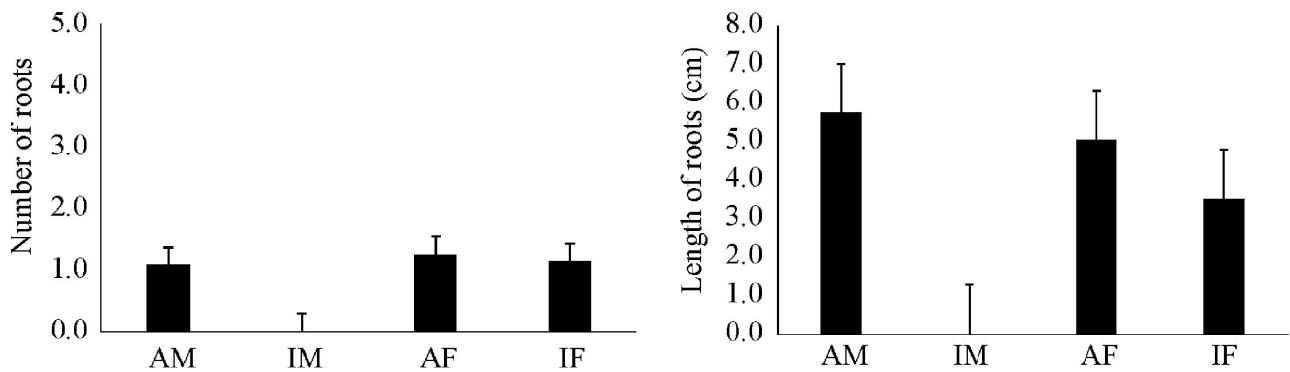

Figure 2 - Number (left) and average length of roots (right) in the bottom of the tray of Araucaria angustifolia cuttings, measured at the exit from the greenhouse after 120 days. Where: $\mathrm{AM}=$ apical male: $\mathrm{IM}=$ intermediate male; $\mathrm{AF}=$ apical female; $I F=$ intermediate female. Bars indicate the standard deviation $(\mathrm{n}=14)$.

Figura 2 - Número (esquerda) e comprimento médio de raízes (direita) no fundo do tubete em estacas de Araucaria angustifolia avaliadas na saída da casa de vegetação aos 120 dias. Onde: AM=macho apical; IM=macho intermediária; $A F=$ fêmea apical; $I M=$ fêmea intermediária. As barras indicam o erro padrão da média $(n=14)$.
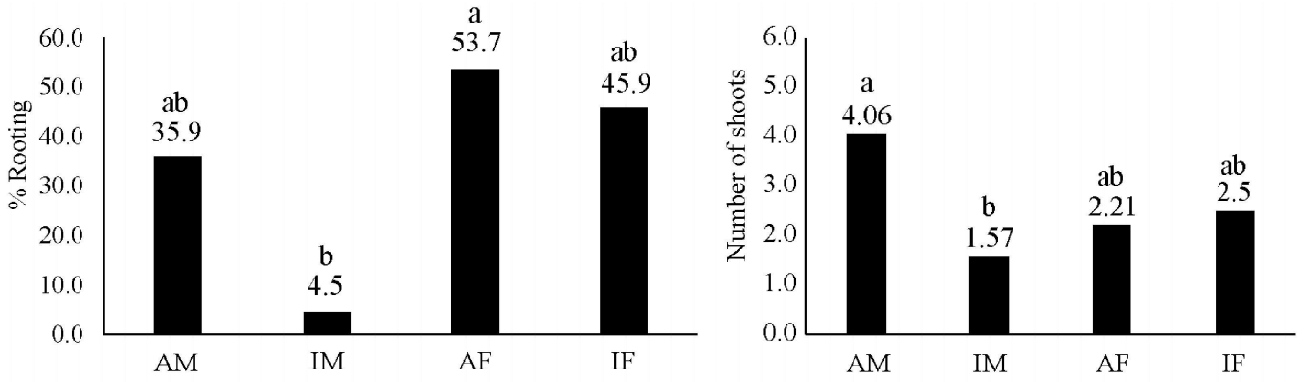

Figure 3 - Rooting percentage in full sunlight area (left) and average number of shoots per cutting (right) of Araucaria angustifolia cuttings after 180 days. Where: $\mathrm{AM}=$ apical male; $\mathrm{IM}=$ intermediate male; $\mathrm{AF}=$ apical female; $\mathrm{IF}=$ intermediate female. Means $( \pm \mathrm{SE})$ with different letters are significantly different (ANOVA and Tukey's HSD test, $\mathrm{P}<0.05$ )

Figura 3 - Porcentagem de enraizamento em área de pleno sol (esquerda) e número médio de brotos por estaca (direita) de Araucaria angustifolia aos 180 dias. Onde: AM=macho apical; IM=macho intermediária; AF=fêmea apical; IM=fêmea intermediária. Médias seguidas por mesma letra não diferem entre si pelo teste de Tukey a 5\% de probabilidade.

Table 1 - Pearson's correlation between survival percentages of Araucaria angustifolia cuttings at the exit of greenhouse (SEGH), exit of shade house (SESH) and rooting in full sunlight area (RFS).

Tabela 1 - Correlação de Pearson entre a sobrevivência das estacas de Araucaria angustifolia na saída da casa de vegetação (SEGH), saída da casa de sombra (SESH) e enraizamento a pleno sol (RFS).

\begin{tabular}{lccc}
\hline & SEGH & SESH & RFS \\
\hline SEGH & 1 & & \\
SESH & $0.84^{* *}$ & 1 & \\
RFS & $0.45^{\text {ns }}$ & $0.73 * *$ & 1 \\
\hline
\end{tabular}

** significant at $1 \%$ level of probability $(\mathrm{p}<0.01)$, ns not significant $(\mathrm{p} \geq 0.05)$

** significativo ao nível de $1 \%$ de probabilidade $(p<0,01)$, ns não significativo $(p>=0.05)$

\section{DISCUSSION}

Vegetative propagation has been an excellent method to support genetic improvement of forest species, allowing the reproduction of genetically superior individuals and providing greater uniformity of the plants (SUTTON, 2002; PIJUT et al., 2011). It was possible to observe in this work that cuttings technique with clones established in a field clonal garden may represent a big advance in the production of Araucaria angustifolia rooted cuttings.

Despite the significant mortality percentages shown by all the treatments at 180 DAI (averages of $79.7 \%$ and $50.2 \%$, respectively, for male and female cuttings, considering that the cuttings that did not take root were dead), the rooting results presented in this study were superior to the observed for Araucaria angustifolia in other works (Figure 3). The best results until now were below 30\% (TESSDORF, 1968; IRITANI; SOARES, 1983; IRITANI et al., 1986; PIRES et al., 2013). It is important to point out that this study used rooted cuttings initially originated from adult trees (26 years 
old), which the morphogenetic capability is known to be lower than in young plants originated by seeds (HACKETT; MURRAY, 1993; HARTMANN et al., 2011; WENDLING et al., 2014). Thus, the results obtained can be considered satisfactory, although the percentages are not yet big enough to recommend the use of this technique for commercial purposes.

Rooting is one of the most critical key points in production of rooted cuttings by vegetative propagation (NEGISHI et al., 2014). The rooting percentages observed in this study were low when compared to other forest species with established vegetative propagation protocols, like Eucalyptus (ALMEIDA et al., 2007; NEGISHI et al., 2014) and Ilex paraguariensis (BITENCOURT et al., 2009; WENDLING et al., 2013). Vegetative propagation by cuttings has been studied for several decades in conifers of the genus Pinus, and the species of this genus are considered of difficult propagation because in the majority of them there is no rhizogenesis if the propagules used are not obtained from juvenile plants generated by seeds (RAGONEZI et al., 2010).

The high mortality percentages observed (Figure 1) during the transition from environments with higher to lower humidity control (greenhouse to shade house) is common in studies related to vegetative propagation of several species like Eucalyptus benthamii x Eucalyptus dunnii (BRONDANI et al., 2010) and Cedrela fissilis (XAVIER et al., 2003). The greater survival percentage of the apical cuttings (Figure 1) can be explained by the bigger concentration of endogenous auxins, once that hormone is produced by meristematic tissues (LUO et al., 2008; DAVIES, 2010) and transported basipetally by the parenchymal cells to the base of cuttings (BOOT et al., 2012; COSTA et al., 2013). Together with other substances, they act in the induction of rhizogenesis (WOODWARD; BARTEL, 2005; SAUER et al., 2013), suggesting the importance of cuttings position in branch (topophysis) on the quantity of rooting promoting substances, like auxins and carbohydrates. These substances carry out an essential function in the construction of necessary cellular structures for all plant physiological processes (LI et al., 2009; DENAXA et al., 2012; MAURIAT et al., 2014).

Apical cuttings have been used with major success in rooted cuttings production for different species. Ferreira et al. (2008) verified greater rooting viability of apical cuttings for atemoya cv. 'Gefner' species, relating those results with the lower lignification of apical branches, the bigger quantity of meristematic cells and a more active metabolism compared to other types of cuttings. In the same way, Hartmann et al. (2011) affirm the great influence of those characteristics on the greater or smaller rooting ability in different types of cuttings. Furthermore, considering the preparation and management of cuttings in a clonal propagation system, the use of apical cuttings is preferable over the intermediate (HOUSE et al., 1998) because for the first type there is no necessity to remove the apex. This practice also reduces the possibility of multiple shoots formation, thus reducing the necessity of labor in the preparation of the propagules (WENDLING; BRONDANI, 2015).

The fact that apical female cuttings showed tendency to present greater root vigor goes together with the survival results of the cuttings in different evaluation periods. The studies conducted until now have suggested the use of apical cuttings for Araucaria angustifolia rooted cuttings production (IRITANI; SOARES, 1983; IRITANI et al., 1986), mainly because the necessity to produce plants with orthotropic growth habit. For some species, there are studies indicating differences in rooting between apical and intermediate cuttings (XAVIER et al., 2003); however, this experiment is the first to assess the use of different types of cuttings originated by orthotropic shoots for Araucaria angustifolia .

The significant rooting reduction at $180 \mathrm{DAI}$ compared to SEGH and SESH, together with not significant correlation between the first two variables, points out the necessity to maintain the cuttings into the greenhouse for a longer period, creating the conditions for them to develop greater survival capabilities in a less controlled environment. The stress created by the alteration of the hydric and illumination conditions, by reducing irrigation and exposing the rooted cuttings to intense illumination (full sunlight), have direct influence on their survival percentage (KRATZ et al., 2015).

Another hypothesis that could justify the reduction of survival values throughout the experiment relates to the climatic conditions at the time of collection, performed in August/2007, in the middle of winter. This may have impaired the rooting of these cuttings in the greenhouse, diminishing their capability to survive in less controlled environment at 120 DAI. This fact was already verified in experiments with the genus

Revista Árvore, Viçosa-MG, v.40, n.6, p.1013-1021, 2016

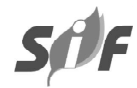


Eucalyptus (WENDLING; XAVIER, 2005; ALMEIDA et al., 2007). In the same way, Trueman et al. (2013) verified a significant effect of the storage temperature of stock plants on the production of shoots and rooting of Corymbia citriodora and Eucalyptus dunnii.

The use of cold-hardy species, of subtropical climate, has been a challenge for genetic improvement programs based on clones, mainly because their recalcitrant characteristic, which reflects directly on their rooting behavior (ELDRIDGE et al., 1994; ASSIS; MAFIA, 2007; BRONDANI et al., 2010). The greater emission of shoots at $180 \mathrm{DAI}$ of the male apical cuttings proves the greater vigor of apical cuttings for Araucaria angustifolia propagation, possibly supported by the juvenility of the propagated material (Figure 3). Several authors have been underlining the importance to use juvenile material in order to propagate forest species, mainly when there is an interest to insert those species in commercial propagation systems (STENVALL et al., 2006; WENDLING et al., 2014).

Despite this, the results obtained until now in the propagation of Araucaria angustifolia are unsatisfactory. Nevertheless, there is a visible evolution in the different methods applied, mainly in the use of methodologies based on rejuvenation of adult material in order to obtain better rooting indexes. Good results were already presented using the mini-cuttings technique, albeit using propagules originated by seeds (PIRES et al., 2013), the recommended method for the massive reproduction of this species (WENDLING et al., 2014).

The methodology presented in this work is promising for the production of Araucaria angustifolia rooted cuttings. Considering that in this moment the cuttings technique is recommended only for the initial phase of the vegetative propagation (recue of selected genotypes), as a base to obtain rooted cuttings to be used for mini-cuttings technique (STUEPP et al., 2014), the methodology here presented can be considered efficient and suggested for this phase of the Araucaria angustifolia cloning procedure.

\section{CONCLUSIONS}

Araucaria angustifolia cuttings from female stock plants and from the apical portion of the branches with orthotropic growth habit presented the greatest rooting ability.

Revista Árvore, Viçosa-MG, v.40, n.6, p.1013-1021, 2016
The cuttings procedures used proved to be adequate to increase the rooting percentages of the species. Considering that this technique is important to produce rooted cuttings for the mini-cuttings technique, we can assume as the presented procedures are considerable efficient.

\section{REFERÊNCIAS}

ALMEIDA, F.D.; XAVIER, A.; DIAS, J.M.M.; PAIVA, H.N. Eficiência das auxinas (AIB e ANA) no enraizamento de miniestacas de clones de Eucalyptus cloeziana F. Muell. Revista Árvore, v.31, p.455-463, 2007.

AMRI, E.; LYARUU, H.V.M.; NYOMORA, A.S.; KANYEKA, Z.L. Vegetative propagation of African Blackwood (Dalbergia melanoxylon Guill. e Perr.): effects of age of donor plant, IBA treatment and cutting position on rooting ability of stem cuttings. New Forest, v.39, p.183-194, 2010.

ASSIS, T.F.; MAFIA, R.G. Hibridação e clonagem. In: BORÉM A. (Eds.). Biotecnologia florestal. Viçosa: Suprema, 2007. p. 93-121.

BITENCOURT, J.; ZUFFELLATO-RIBAS, K.Z.; WENDLING, I.; KOELER, H. Enraizamento de estacas de erva-mate (Ilex paraguariensis A. St.Hill.) provenientes de brotações rejuvenescidas.

Revista Brasileira de Plantas

Medicinais, v.11, p.277-281, 2009.

BOOT, K.J.; LIBBENGA, K.R.; HILLE, S.C.; OFFRINGA, R.; VAN DUIJN, B. Polar auxin transport: an early invention. Journal of Experimental Botany, v.63, p.4213-4218, 2012.

BRONDANI, G.E.; GROSSI, F.; WENDLING, I.; DUTRA, L.F.; ARAUJO, M.A. Aplicação de IBA para o enraizamento de miniestacas de Eucalyptus benthamii Maiden e Cambage x Eucalyptus dunnii Maiden. Acta Scientiarum. Agronomy, v.32, p.667-674, 2010.

CARVALHO, P.E.R. Espécies arbóreas brasileiras. Brasília: Embrapa Informação Tecnológica; Colombo: Embrapa Florestas. 2003. 1039 p.

COSTA, C.T.; DE ALMEIDA, M.R.; RUEDELL, C.M.; SCHWAMBACH, J.; MARASCHIN, F.D.S.; 
FETT-NETO, A.G. When stress and development go hand in hand: main hormonal controls of adventitious rooting in cuttings. Frontiers in Plant Science, v.4, p.1-19, 2013.

DAVIES, P.J. The plant hormones: their nature, occurrence, and functions. In: DAVIES, P.J. (ed) Plant hormones. Springer: Netherlands, 2010. p. 1-15.

DELUCIS, R.A.; GATTO, D.A.; STANGERLIN, D.M.; BELTRAME, R.; TREVISAN, R. Qualificação da madeira de três espécies de coníferas oriundas de reflorestamentos jovens. Scientia

Forestalis, v.41, n.100, p.477-484, 2013.

DENAXA, N.K.; VEMMOS, S.N.; ROUSSOS, P.A. The role of endogenous carbohydrates and seasonal variation in rooting ability of cuttings of an easy and a hard to root olive cultivars (Olea europaea L.). Scientia

Horticulturae, v.143, p.19-28, 2012

DIAS, P.C.; OLIVEIRA, L.D.; XAVIER, A.; WENDLING, I. Estaquia e miniestaquia de espécies florestais lenhosas do Brasil.

Pesquisa Florestal Brasileira, v. 32, n.72, p.453-462, 2012.

ELDRIDGE, K.; DAVIDSON, J.; HARDWIID, C.; VAN WYK, G. Mass vegetative propagation. In: ELDRIDGE, K.; DAVIDSON, J.; HARDWIID, C.; VAN WYK, G. (Eds.). Eucalypt

domestication and breeding. Oxford: Clarendon Press, 1994. p.228-246.

FERREIRA, G.; FERRARI, T.B.; PINHO, S.Z.; SAVAZAKI, E.T. Enraizamento de estacas de atemoieira 'Gefner' tratadas com auxinas.

Revista brasileira de fruticultura, v. 30 , p.1083-1088, 2008.

HACKETT, W.P.; MURRAY, J.R. Maturation and rejuvenation in woody species. In: AHUJA, M.R. (Ed.). Micropropagation of woody plants. Dordrecht: Kluwer Academic Publishers, 1993. p.93-105.

HARTMANN, H.T.; KESTER, D.E.; DAVIES, F.T.; GENEVE, R.L. Plant propagation:

principles and practices. 8th ed. São Paulo: Prentice-Hall, 2011.915p.
HOUSE, S.; DIETERS, M.; JOHNSON, M.; HAINES, $\mathrm{R}$. Inhibition of orthotropic replacement shoots with auxin treatment on decapitated hoop pine, Araucaria cunninghamii, for seed orchard management. New Forests, v. 16, p.221-230, 1998.

HUNT, M.A.; TRUEMAN, S.J.; RASMUSSEN, A. Indole-3-butyric acid accelerates adventitious root formation and impedes shoot growth of Pinuselliottii var. elliottii $\times$ P. caribaea var. hondurensis cuttings. New Forest, v.41, p.349-360, 2011.

IRITANI, C. Aspectos múltiplos da cultura in vitro da Araucaria angustifolia (BERT) O. Ktze. Revista Floresta, v.27, n.1/2, p.141-142, 1997.

IRITANI, C.; SOARES, R.V. Indução do enraizamento de estacas de Araucaria angustifolia através da aplicação de reguladores de crescimento. Silvicultura, v.8, n.28, p.313$317,1983$.

IRITANI, C.; SOARES, R.V.; GOMES, A.V. Aspectos morfológicos da ação de reguladores do crescimento em estacas de Araucaria angustifolia (Bert) O. Ktze. Acta Biológica Paranaense, v. 15, n.1/2/3/4, p.1-20, 1986.

KOCH, Z.; CORRÊA, M.C. Araucária: a floresta do Brasil meridional. Olhar Brasileiro. Curitiba, 2002. 167p.

KRATZ, D.; WENDLING, I.; PIRES, P.P.; STUEPP, C.A. Enraizamento de miniestacas de erva mate em substratos a base de casca de arroz e fibra de coco. Revista Floresta, v.45, n.3, 2015.

KY-DEMBELE, C.; TIGABU, M.; BAYALA, J.; SAVADOGO, P.; BOUSSIM, I. J.; ODÉN, P.C. Clonal propagation of Khaya senegalensis: the effects of stem length, leaf area, auxins, smoke solution, and stock plant age. International Journal of Forestry Research, v.2011, p.1-10, 2011.

LI, S.W.; XUE, L.; XU, S.; FENG, H.; AN, L. Mediators, genes and signalling in adventitious rooting. The Botanical Review, v.75, n.2, p.230-247, 2009.

LUO, J.; ZHANG, J.; WANG, Y. Changes in endogenous hormone levels and redox status

Revista Árvore, Viçosa-MG, v.40, n.6, p.1013-1021, 2016 
during enhanced adventitious rooting by rare earth element neodymium of Dendrobium densiflorum shoot cuttings. The Journal of Rare Earths, v.26, p.869-874, 2008.

MAJADA, J.; MARTÍNEZ-ALONSO, C.; FEITO, I.; KIDELMAN, A.; ARANDA, I.; ALÍA, R. Minicuttings: an effective technique for the propagation of Pinus pinaster. New Forest, v.41, p.399-412, 2011.

MATTOS, P.P.; DE BORTOLI, C.; MARCHESAN, R.; ROSOT, N. C. Caracterização física, química e anatômica da madeira de Araucaria angustifolia (Bert.) O. Kuntze. Colombo: Embrapa, 2006. 4p. (Comunicado técnico, 160).

MAURIAT, M.; PETTERLE, A.; BELLINI, C.; MORITZ, T. Gibberellins inhibit adventitious rooting in hybrid aspen and Arabidopsis by affecting auxin transport. The Plant Journal, v.78, n.3, p.372-384, 2014.

MCMAHON, T.V.; HUNG, C.D.; TRUEMAN, S.J. Clonal maturation of Corymbia torelliana $\times C$. citriodora is delayed by minimal growth storage. Australian Forestry, v.77, n.1, p. 9-14, 2014.

MOREIRA-SOUZA, M.E.; CARDOSO, E.J.B.N. Dependência micorrízica de Araucaria angustifolia (Bert.) O. Ktze. sob doses de fósforo. Revista Brasileira de Ciência do Solo, v.26, p.905912, 2002.

NEGISHI, N.; NAKAHAMA, K.; URATA, N.; KOJIMA, M.; SAKAKIBARA, H.; KAWAOKA, A. Hormone level analysis on adventitious root formation in Eucalyptus globulus. New Forests, v.45, p.577-587, 2014.

PIJUT, P.M.; WOESTE, K.E.; MICHLER, C.H. Promotion of adventitious root formation of difficult-to-root hardwood tree species.

Horticultural Reviews, v.38, p.213-251, 2011.

PIRES, P.P.; WENDLING, I.; BRONDANI, G. Ácido indol butírico e ortotropismo na miniestaquia de Araucaria angustifólia. Revista Árvore, v.37, p.393-399, 2013.

RAGONEZI, C.; KLIMASZEWSKA, K.; CASTRO, M.R.; LIMA, M.; DE OLIVEIRA, P.; ZAVATTIERI,
M.A. Adventitious rooting of conifers: influence of physical and chemical factors. Trees, v.24, p.975-992, 2010.

SAUER, M.; ROBERT, S.; KLEINE-VEHN, J. Auxin: simply complicated. Journal of Experimental Botany, v.64, p.2565-2577, 2013.

SAYA, R.A.; MANKESSI, F.; TOTO, M.; MARIEN, J.N.; MONTEUUIS, O. Advances in mass clonal propagation of Eucalyptus urophylla $\mathrm{x}$ E. grandis in Congo. Bois Et Forets Des Tropique, v.297, p.15-25, 2008.

STENVALL, N.; HAAPALA, T.; PULKKINEN, P. The role of a root cutting's diameter and location on the regeneration ability of hybrid aspen.

Forest Ecology and Management, v.237, p.150-155, 2006.

STUEPP, C.A.; ZUFFELLATO-RIBAS, K.C.; WENDLING, I.; KOEHLER, H.S.; BONA, C. Vegetative propagation of mature dragon trees through epicormic shoots. Revista Bosque, v.35, n.3, p.333-341, 2014.

SUTTON, B. Commercial delivery of genetic improvement to conifer plantations using somatic embryogenesis. Annals of Forest Science, v.59, p.657-661, 2002.

TESSDORF, J.N.F. Enraizamento en estacas de híbridos de Araucaria com ayuda de hormonas. In: CONGRESSO FLORESTALARGENTINO, 1968, La Barrnacosa. Anais... La Barrnacosa, 1968. p. 290-291.

TRUEMAN, S.J.; MCMAHON, T.V.; BRISTOW, M. Production of cuttings in response to stock plant temperature in the subtropical eucalypts, Corymbia citriodora and Eucalyptus dunnii. New Forests, v.44, p.265-279, 2013.

WENDLING, I.; BRONDANI, G. Vegetative rescue and propagation of Araucaria angustifolia. Revista Árvore, v.39, n.1, p.93-104, 2015.

WENDLING, I.; BRONDANI, G.E.; BIASSIO, A.D.; DUTRA, L.F. Vegetative propagation of adult Ilex paraguariensis trees through epicormic shoots. Acta Scientiarum. Agronomy, v.35, n.1, p.117-125, 2013.

Revista Árvore, Viçosa-MG, v.40, n.6, p.1013-1021, 2016 
WENDLING, I.; BRONDANI, G.E.; DUTRA, L.F.; HANSEL, F.A. Mini-cuttings technique: a new ex vitro method for clonal propagation of sweetgum. New Forest, v.39, p.343-353, 2010.

WENDLING, I.; DUTRA, L.F.; GROSSI, F. Produção e sobrevivência de miniestacas e minicepas de erva-mate cultivadas em sistema semi-hidropônico. Pesquisa Agropecuária Brasileira, v.42, p.289-292, 2007.

WENDLING, I.; DUTRA, L.F.; HOFFMANN, H.A.; BETTIO, G.; HANSEL, F. Indução de brotações epicórmicas ortotrópicas para a propagação vegetativa de árvores adultas de Araucaria angustifolia. Agronomía Costarricense, v.33, p.309-319, 2009.

WENDLING, I.; STUEPP, C.A.; ZUFFELLATORIBAS, K.C. Araucaria angustifolia grafting techniques, environments and origin of propagation material. Revista Bosque, v.37, n.2, p.285-293, 2016.

WENDLING, I.; TRUEMAN, S; XAVIER, A.
Maturation and related aspects in clonal forestrypart II: reinvigoration, rejuvenation and juvenility maintenance. New Forests, v. 1, p.1-14, 2014.

WENDLING, I.; XAVIER, A. Influência do ácido indol butírico e da miniestaquia seriada no enraizamento e vigor de miniestacas de clones de Eucalyptus grandis. Revista Árvore, v.29, p.921-930, 2005.

WOODWARD, A.W.; BARTEL, B. Auxin: regulation, action, and interaction. Annals of Botany, v.95, p.707-735, 2005.

XAVIER, A.; SANTOS, G.A; OLIVEIRA, M.L. Enraizamento de miniestacas caulinares e foliares na propagação vegetativa de cedro-rosa (Cedrela fissilis Vell.). Revista Árvore, v.27, p.351-356, 2003.

ZANETTE, F.; OLIVEIRA, L.D.S.; BIASI, L.A. Grafting of Araucaria angustifolia (BERTOL.) kuntze through the four seasons of the year. Revista Brasileira de Fruticultura, v.33, p.1364-1370, 2011. 